\title{
Nervous System Finding
}

National Cancer Institute

\section{Source}

National Cancer Institute. Nervous System Finding. NCI Thesaurus. Code C36280.

Symptoms, physical examination results, and/or laboratory test results related to the nervous system. 